\title{
THE TECTONIC EVOLUTION OF THAT PORTION OF THE GUIANA SHIELD REPRESENTED IN GUYANA - AN EVALUATION OF THE PRESENT STATUS OF INVESTIGATIONS AND CORRELATIONS ACROSS THE GUIANA SHIELD
}

\author{
SOBHARAM SINGH*
}

\begin{abstract}
In Guyana four significant tectonic episodes can be recognized.
The earliest (3000-2700 m.y.) is the Guriense fold belt which is comprised by the Kanuku Complex. The rocks are predominantly migmatites, but some granulites also occur. The second (2000$-1800 \mathrm{~m} . \mathrm{y}$.) is the Trans-Amazonian episode of folding and regional metamorphism, which affected the eugeosynclinal rocks of the Barama-Mazaruni Assemblage and the Kwitaro Group, as well as the shelf sedimentarynvolcanic sequences of the Muruwa-Iwokrama Formations, and the Kuyuwini Group. Those sequences were intruded by the post-tectonic rocks of the Appinitic Intrusive Suite, and the Akawaiian granitic rocks. The third (about $1200 \mathrm{~m} . \mathrm{y}$.) is named $\mathbf{K}^{\prime}$ Mudko episode, and is marked by cataclasis on a regional scale, while the fourth episode (Mesozoic) is the formation of the Takutu graben in southern Guyana.
\end{abstract}

RESUMO Na República da Guiana podem ser reconhecidos quatro episódios tectónicos principais. O primeiro deles (3000-2 700 m.a.) é representado pela faixa de dobramentos Guriense, que compreende o Complexo de Kanuku. Suas rochas são predominantemente migmatitos, mas gra* nulitos também foram assinalados. O segundo (2000-1 800 m.a.) é o episódio tectônico Transamazônico, que produziu dobramentos intensos e metamorfismo regional sobre as rochas eugeossinclinais do Complexo Barama-Mazaruni e do Grupo Kwitaro, bem como sobre as sequiências vulcánico-sedimentares de plataforma que constituem as Formaçðes Muruwa-Iwokrama, e o Grupo Kuyuwini. Essas unidades sofreram intrusões das rochas pós-tectônicas da seqüência intrusiva Appinítica e dos granitos Akawaiianos. O terceiro (cerca de 1200 m.a.) é denominado episódio tectônico $\mathrm{K}^{\prime}$ Mudko, sendo caracterizado por importante cataclase regional. E, finalmente, o quarto (Mesozóico) é representado pela formação do graben do Takutu.

INTRODUCTION Those of us who have been fortunate, or perhaps unfortunate, to have worked in the Precambrian know only too well that the study of the Precambrian is sometimes frustrating, sometimes rewarding but at all times challenging. In the Guiana Shield, nature, not content with the inherent complexities of the geology, has sought to impose upon us the additional difficulties of dense amazonian forest cover and deep tropical weathering. It is doubtful whether in our lifetime we would be able to solve all the problems of the Guiana Shield. We are all conscious of the fact that the study of the Guiana Shield is an on-going one and that periodically there is need for stock-taking. It is in this perspective that $I$ have attempted to put together for the Brazilian XXVI Geological Congress, the information gathered to the present time in Guyana and have attempted on this basis to reconstruct the tectonic evolution of that portion of the Guiana Shield represented in Guyana. I will also look briefly at the possible correlations of the major tectonic and stratigraphic elements across the Guiana Shield.

In Guyana we can recognise four significant tectonic episodes.

1. The earliest episode occurs in the Archaean and represents a period of folding and regional metamorphism dated as 3000-2700 m.y. For the Tectonic Map of South America it had been agreed that this episode by named the Guriense.

*Geological Survey and Mines Dept. P.O. Box 1028, Georgetown, Guyana 
2. Another significant and widespread episode of folding and regional metamorphism occurs in the Lower Proterozoic and is dated as 2000-1800 m.y. This tectonic episode is recognised throughout the Guiana Shield and has been variously named: the Trans-Amazonian episode, the Guyanensis or the Akawaiian episode.

3. The third episode is marked by cataclasis on a regional scale occurring in Middle Proterozoic times and well dated at approximately $1200 \mathrm{~m} . \mathrm{y}$. In Guyana it is referred to as the $K^{\prime} M u d k u$ episode and in Suriname as the Nikerian episode.

4. The fourth significant tectonic episode recognised in Guyana is the Takutu episode marked by block faulting which has given rise to the Takutu graben. This episode of rifting occurred in the Mesozoic in Jurassic-Cretaceous times.

Now let us look at the main characteristics of stratigraphy, magmatism and geotectonic cycles of the belts affected by these tectonic episodes, and of the activities in the post or intertectonic periods.

The Archaean Guriense fold belt The Archaean Guriense fold belt is comprised by the Kanuku Complex which underlies some 8,000 square miles of the southern portion of the country. The rocks are predominantly veined or migmatitic acid biotite gneisses \pm \pm (garnet, cordierite, sillimanite). Berrange (1972) describes subordinate amphibolites, and quartzite-banded ironstone formations. Granulites, ranging in composition from acid to basic occur as bodies within the gneisses.

The gneisses have suffered regional metamorphism in the sillimanite-almandine subfacies of the almandine amphibolite facies. Locally in the cores of tight folds extreme conditions led to the attainment of granulite facies grade and these granulites have resisted the overall plastic deformation of the gneisses and remain preserved as rotated discordant bodies. Hypersthene bearing rocks of granulitic texture, ranging in composition from acid to basic, and closely. resembling charnockite suites described from other shield areas of the world, occur in the Kanuku Complex. Detailed studies have shown, however, that the petrogenesis of these rocks is quite different from charnockites "sensu stricto" and so they have been referred to as hypersthene-bearing granulites (Singh, 1966).

The rocks of this Archaean fold belt appear to represent metamorphosed eugeosynclinal sediments containing a significant amount of acid plutonism.

At least two episodes of folding are recognised in the gneisses of the Kanuku Complex, the later being in the Trans-Amazonian. The rocks of this. Guriense fold belt have been affected by the $\mathrm{K}$ 'Mudku cataclastic episode as well as the Takutu episode.

A K-Ar riebeckite age of $2595 \pm 125 \mathrm{~m}$.y. was obtained from a granite suggested to form part of the Kanuku Complex and an age of 3000 m.y. was obtained from the Imataca Complex in Venezuela, with which the Kanuku Complex is correlated, so that the Guriense tectonic episode has been dated as 3000-2700 m.y.

The rocks of the Kanuku Complex can reasonably be correlated with the Adampada-Fallawatra Group of Suriname, the Ile de Cayenne Group of French Guiana and the Imataca Complex of the Guyana territory of Venezuela. It seems very likely that large portions of the shield in Brazil, Venezuela, Suriname and French Guiana, which are uncorrelated, would fall in this tectonic-stratigraphic horizon.

The Lower Proterozoic Trans-Amazonian fold belts The geotectonic cycles and stratigraphic units recognised in these fold belts are outlined on the Provisional Tectonic Map.

A. THE EUGEOSYNCLINAL FACIES 1. The Barama-Mazaruni Assemblage. These 
rocks which occur in the northern portion of the country, are eugeosynclinal in character and consist of -

a) the Barama Group principally of pelitic metasediments with metamorphosed lavas and pyroclastics, and containing manganiferous phyllites and gondites; and b) the $M a-$ zaruni Group which appears to overlie the Barama Group by transition. The Mazaruni Group is comprised by the Cuyuni Formation of pebbly greywacke, sandstones and intram formational conglomerates with acid to basic volcanics, and the Haimaraka Formation of mudstones and greywackes with little volcanism.

The rocks of the Barama-Mazaruni Assemblage have been folded, invaded by syntectonic granites and metamorphosed generally in the greenschist facies but reaching the upper amphibolite facies in the north east.

2. The Kwitaro Group. This group has recently been defined by Berrange (1972) in the southern part of the country. Rocks of this group are represented by five meta-sedimentary formations occurring as enclaves in the South Savannas Granite Complex. Pelitic and semi-pelitic metasediments, now represented mainly by phyllites, meta-siltstones, schists and gneisses predominate, with variable representations of amphibolites, quartzites, and meta-acid igneous rocks. A quartz pebble conglomerate has been recorded locally. Shallow water sedimentation is indicated.

The rocks of this Group have been strongly folded and affected by regional metam morphism reaching the sillimanite-cordierite-muscovite-almandine subfacies of the amphibolite facies. Contact metamorphism, related to the intrusion of the South Savannas granite, is evident in places.

Rocks of the Kwitaro Group have been correlated with the Barama-Mazaruni Assemblage.

Correlations across the Guiana Shield The predominantly pelitic facies represented in the Barama Group has been correlated whith the Paramaca of French Guiana and Suriname; the Cariachapo of Venezuela and the Amapá Formation of Brazil. The predominantly arenaceous Mazaruni Group has been correlated with the Armina Series of Suriname; the Orapu-Bonidoro Series of French Guiana and the Pastora Series of Venezuela. I do not have information about its equivalent in Brazil.

B. THE EPIGONTINENTAL OR SHELF FACIES Rocks of the Muruwa-Iwokrama Formations (McConnell \& Williams 1970) and the Kuyuwini Group (Berrange 1972), which are open folded shallow water sediments and volcanics with very low grade of metamorphism are suggested to be epicontinental or shelf facies equivalent of the eugeosynclinal rocks of the Barama-Mazaruni-Kwitaro Groups.

1. The Muruwa-Iwokrama Formations These rocks occur immediately to the north of the Takutu graben. The Muruwa Formation is comprised by ortho-quartzites which are overlain by the Iwokrama volcanic suite of acid intermediate tuffs and lavas associated with co-magmatic intrusive adamellite granophyre and feldspar porphyry.

A K-Ar muscovite age of $1915 \pm 80 \mathrm{~m} . \mathrm{y}$. was given by one of the acid volcanics. 2. The Kuyuwini Group Rocks of this group (Berrange 1972) are mainly rhyodacitic lavas and tuffs and co-magmatic intrusive granitic rocks, porphyries and granophyres. Correlation of these rocks with the Muruwa-Iwokrama Formations is justified.

Correlations across the Guiana Shield

a) The ortho-quartzitic Muruwa Formation has been correlated with the Ston-Rosebel Formations of Suriname and the Cinaruco Formation in Venezuela. No equi* 


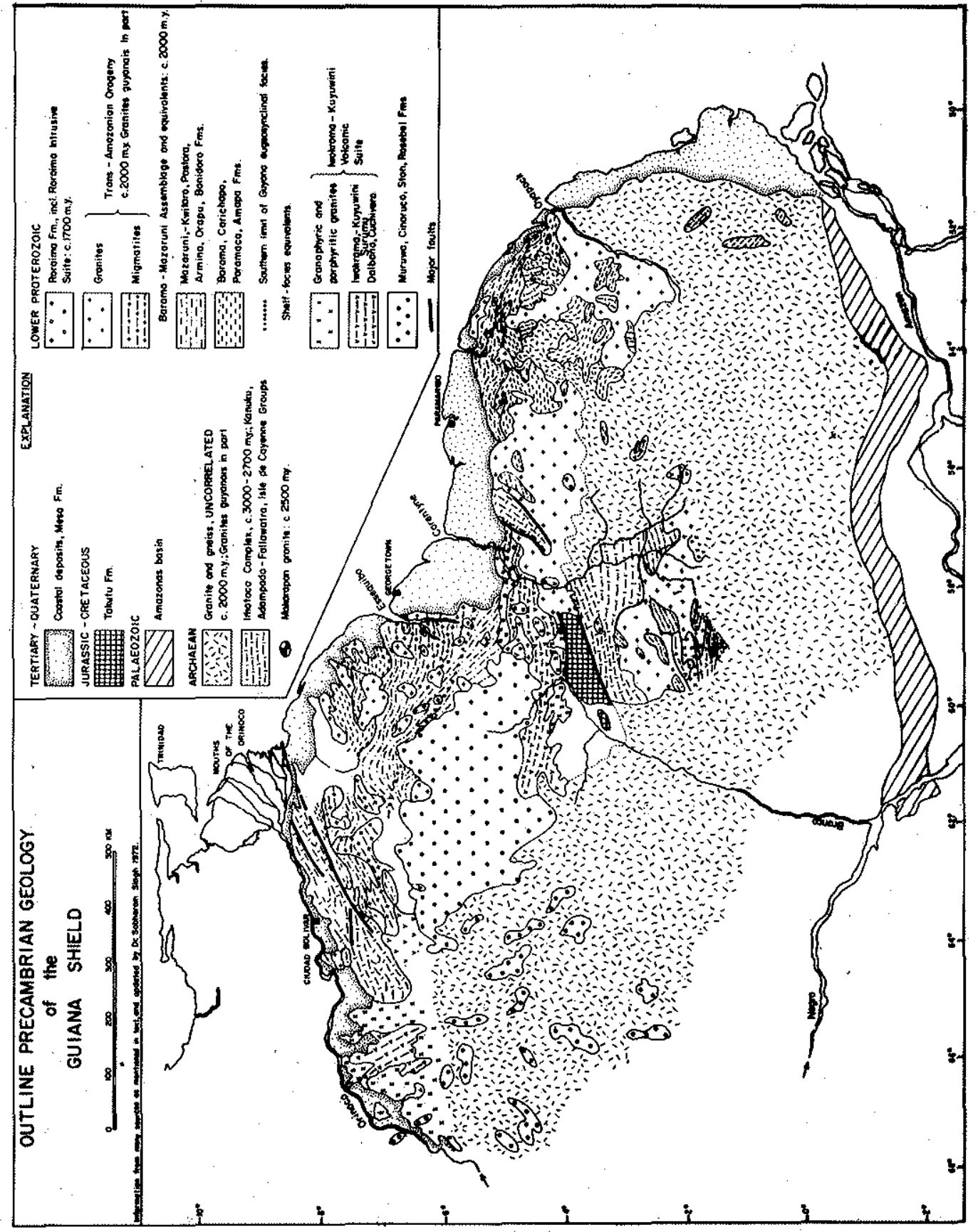


valents have been recognised in French Guiana as yet and information is not available from Brazil.

b) The acid-intermediate Iwokrama-Kuyuwini volcanics have been correlated with the Dalbana Formation of Suriname, the Surumu Volcanics of Brazil and the Cuchivero of Venezuela.

c) The correlations of the co-magmatic granophyric and porphyritic granites of the Iwokrama-Kuyuwini suite is uncertain because of unavailability of information from the other sections of the shield.

\section{Post-tectonic magmatism}

1. The Appinitic Intrusive Suite. Berrange (1972) describes these rocks from the southern part of the country and places their emplacement as earlier than the post-tectonic granites. They are mainly small co-magmatic intrusive plutons ranging from ultrabasic to acid in composition and are characterised by the green-brown or blue-green hornblende.

2. The Akawaiian Granite Episode. This was a very significant episode in Guyana and in the shield as a whole in which foliated syn-tectonic and non-foliated post-tectonic granites of great textural and lithological varieties were emplaced. Granite bodies vary in size from small stocks and plutons to batholiths thousands of square miles as in the South Savannas Granite batholith in the south, and contact metamorphism of host country rocks in varying degrees is evident (Singh 1964, 1969). In Guyana, as most certainly in other parts of the Guiana Shield, controversy continues as to the age of emplacement; the mode of emplacement, i.e. magmatism versus migmatisation and whether subsequent mobilisation has occurred. Age determinations in these granites in Guyana point to an age of about $1850 \mathrm{~m}$.y. To give you an idea of the kinds of problems which arise, it may be of interest to point out that Berrange (1972) from his study of the southern part of the country, recognises two main types of granites: the grey granites and the pink granites. The grey granites are predominant and eminently represented in the South Savannas batholith. He considers that the pink granites represent re-mobilised grey granites which have suffered potash metasomatism, and are therefore younger than the grey granites. He cites instances of the pink granites intruding the grey granites and considers that two $\mathrm{K}$-Ar biotite ages of $170 \mathrm{l} \pm 28 \mathrm{~m}$.y. and $1838 \pm 30 \mathrm{~m}$.y. given by two pink granites are indicative of the age of reactiviation of the South Savannas Granite, itself dated at $1845 \pm 130$ m.y. The writer feels that on the basis of only two ages, one of which is identical with the South Savannas Granite, and on the degree of accuracy of biotite ages, this is a premature conclusion. Even if such disparities were to be substantiated by many age determinations, they can alternatively suggest that some intrusion took place in the early post-tectonic phase and others in the late post-tectonic phase; or that biotites were re generated in dynamic movements marking the final quiesence of the tectono-thermal episode.

\section{Correlations of the Akaiwaiian Granites}

These granites are widespread in the Guiana Shield in Suriname and French Guiana, in Venezuela and in Brazil.

The Roraima Formation PLATFORM DEPOSITS The rocks of the Roraima Formation constitute the "tabular Proterozoic" which unconformably overlies rocks of the Trans-Amazonian fold belt and the post tectonic Akawaiian granites. Detailed investi- 
gations in process indicate that the Lower Roraima Formation is characteristically fluvio-deltaic derived from a source to the north east of the present outcrops.

Dolerite sills and dykes of the Roraima Intrusive Suite which have intruded and contact metamorphosed the Roraima Formation have been dated $1695 \pm 66$ m.y., thus suggesting an interval of between 1800-1700 m.y. for the deposition of the rocks of the Roraima Formation (McConnell and Williams 1970).

Correlation of the Roraima across the Shield The Roraima Formation is widespread in the Guiana Shield. It extends westwards from the Pakaraima Mountains in Guyana into Brazil and Venezuela, with many outliers in the latter country. Eastwards into Suriname, it is represented by a small outlier in Tafelberg and is absent in French Guiana.

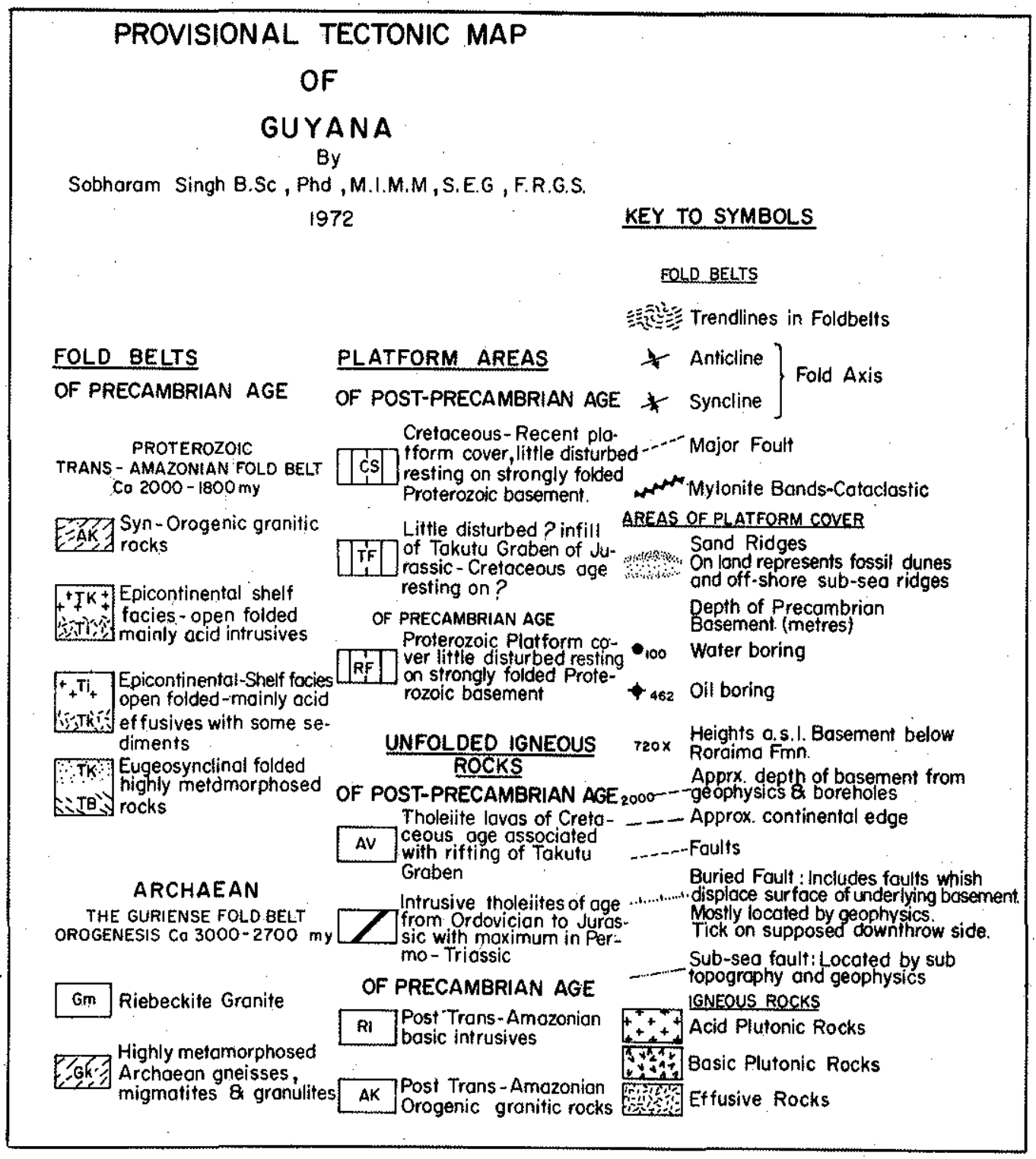




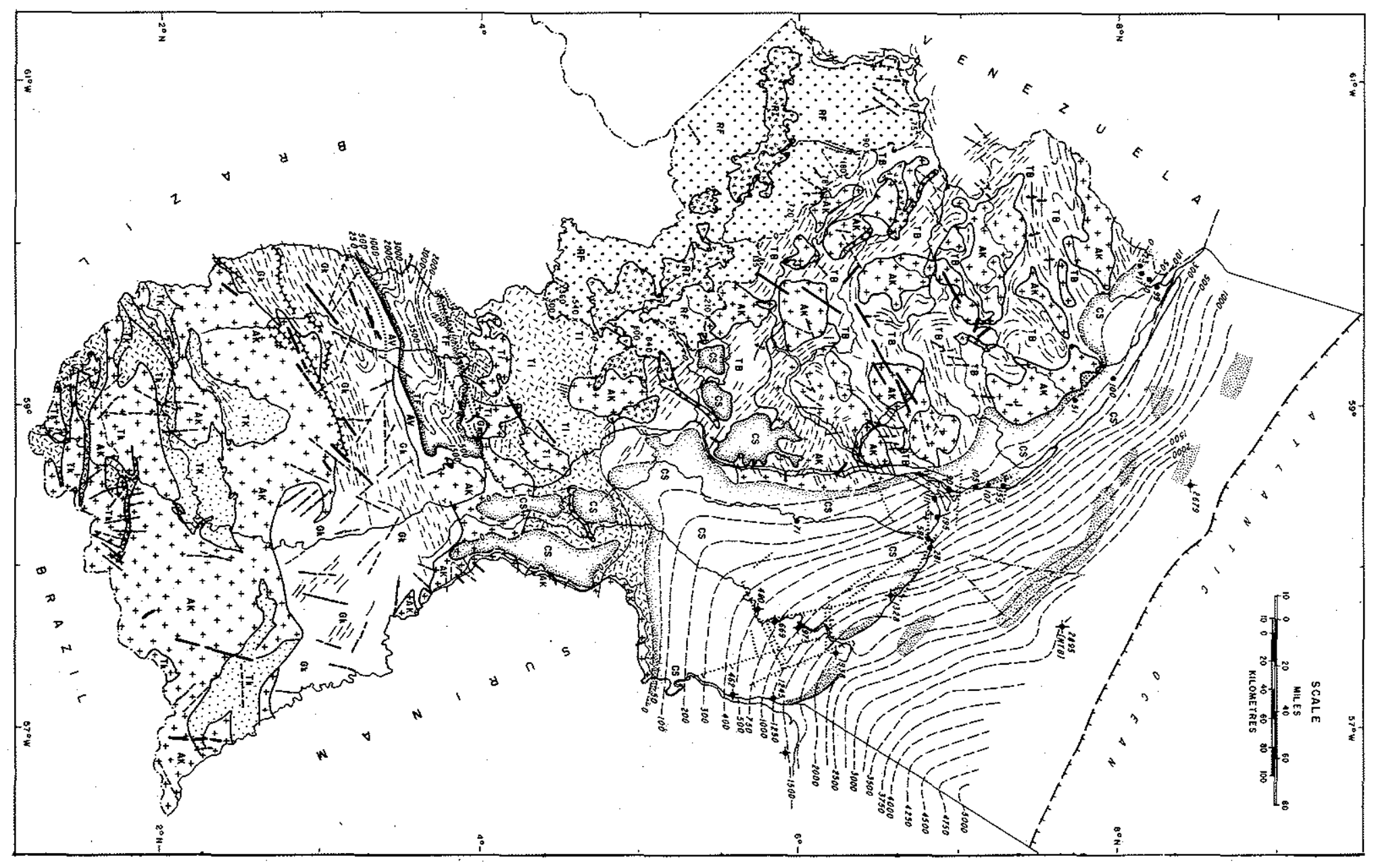




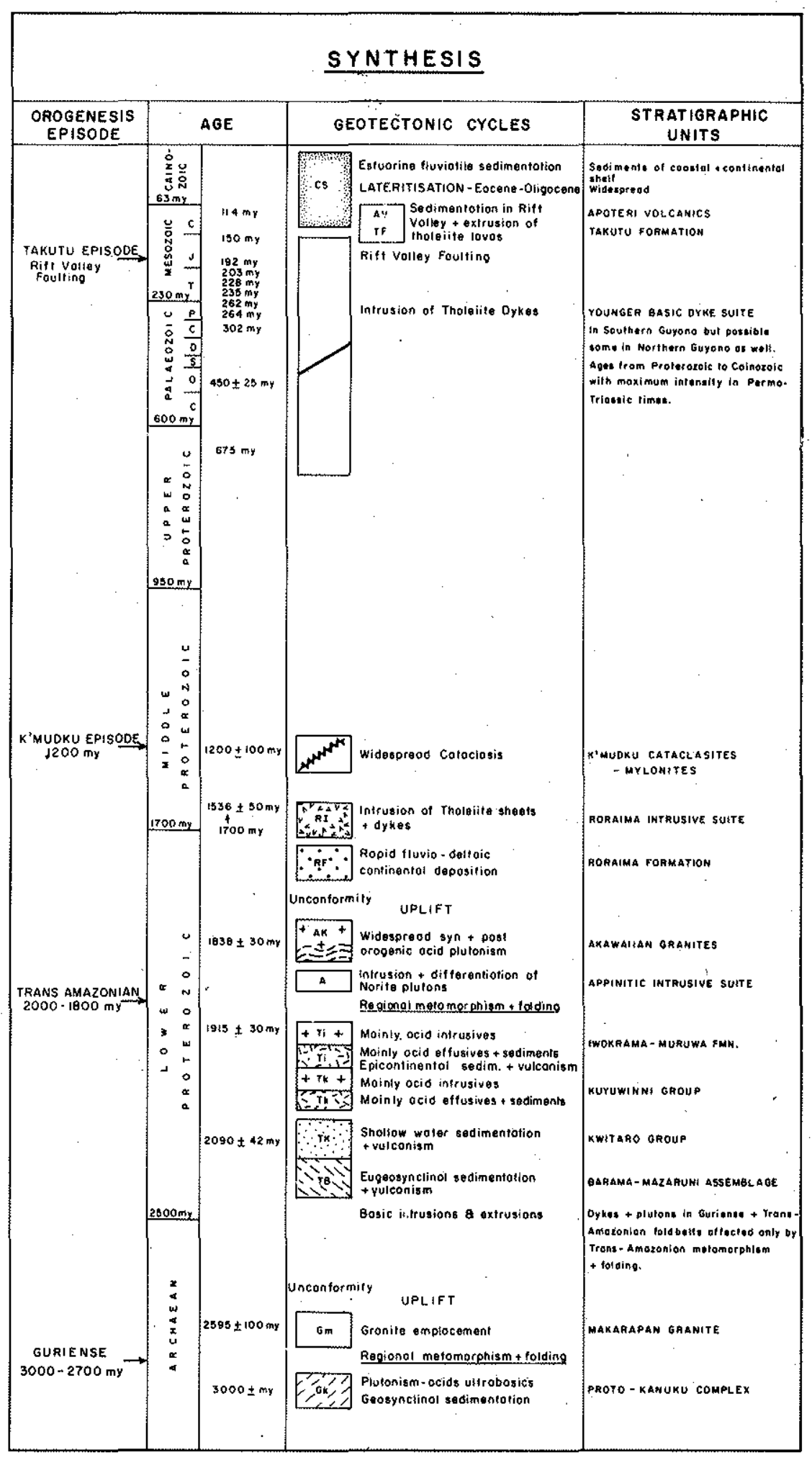


The K'mudku cataclastic episode The country rocks south of the Takutu graben have been cut by belts of intense shearing and cataclasis culminating locally in mylonites and pseudotachylites.

In the belts affected by this cataclasis, there has been regeneration of biotites and this episode has been reliably dated at $1200 \pm 100 \mathrm{~m} . \mathrm{y}$.

This cataclasis episode has been recognised in eastern Suriname as the Nickerian episode and should occur in areas of Brazil bordering the southern complex of Guyana.

Post Precambrian Tectono-Thermal activity 1. Younger Basic Dyke Suite There appears to have been little activity in the Guiana portion of the Guiana Shield during Upper Proterozoic and Palaeozoic times. The only activity evident is the intrusion of the tholeiite dykes of ages ranging from Ordovician to Cretaceous with a maximum intensity in Permo-Triassic times.

2. The Takutu Episode Rifting and associated extrusion of tholeiitic lavas sometime in the Jurassic produced the Takutu graben in the south central part of the country. This graben contains an estimated 20,000 feet of sediments, the upper 300 feet of which appear to be of the continental red beds type and dated on fossil evidence as Jurassic-Lr. Cretaceous in age (van der Hammen and Burger, 1966).

This period of rifting may well have produced the Bakhuis-Fallawatra horst to the east in Suriname and must continue westwards into Brazil.

3. The Coastal Sediments, Platform deposits Estuarine-fluviatile sedimentation from Cretaceous to Recent produced, during a series of marine incursions and regressions, a thick series of generally flat lying unmetamorphosed sands and clays on the coastal continental shelf of the country. These sediments vary in thickness from a few tens of feet in the coastal belt to several thousands of feet near the continental edge.

These are the equivalent of the coastal and continental shelf deposits of Venezuela, Suriname, French Guiana and Brazil.

Acknowledgements In preparing this paper the writer has drawn liberally from the works of many geologists in Guyana, in particular Dr. J. P. Berrange, Mr. C. N. Barron in the south of the country and Dr. R. B. McConnell.

\section{REFERENCES}

BERRANGE, J. P. - 1972 - The Tectonic/Geological Map of Southern Guyana. Paper presented at IX Inter-Guiana Geol. Conf. Puerto Ordaz, Venezuela

MCCONNELL, R.B. and WILLIAMS, - 1970 - Distribution and provisional correlation of the Guiana Shield. Proc. Eighth Guiana Geol. Conf. Georgetown, 1969

SINGH, S. - 1964 - The Younger Granite Group: Study of (i) the Quartzstone-Aremu Batholith; (ii) the Rupa Granite; (iii) the Kopang Granite. SS 1/64. Geol. Surv. Brit. Guiana. Unpublished Report, 14 pp.

SINGH, S. - 1966 - Orthopyroxene-bearing rocks of charnockitic affinities in the South Savannas-Kanuku Complex of British Guiana. J. Petrol. London, 7(2): 171-192

SINGH, S. - 1969 - The Granite-Gneiss Problem. Evidence from Guiana Shield rocks of Southern Guyana. Proc. 7th Inter-Guiana Geol. Conf., Paramaribo 1966; pp. 131-144

van der HAMMEN, T. and BURGER, D. - 1966 - Pollen flora and age of the Takutu Formation (Guyana); Leid. geol. Meded., 38: 173-180 